\title{
A Case of Synovial Sarcoma Arising from the Cervical Region
}

\author{
Yusuke Ayani ${ }^{1)}$, Noriko Taniguchi ${ }^{1)}$, Norio Suzuki ${ }^{1)}$, Shinpei Ichihara ${ }^{1)}$, \\ Keiko Hasegawa $^{1)}$, Masaaki Higashino ${ }^{1)}$, Koutetsu Lee ${ }^{1)}$, Tetsuya Terada ${ }^{1)}$, \\ Ryo Kawata ${ }^{1)}$, Yoshitaka Kurisu ${ }^{2)}$ and Motomu Tsuji ${ }^{2)}$
}

\begin{abstract}
Synovial sarcomas account for $5 \%$ of all pediatric soft tissue sarcomas, and primarily arise in the extremities. We report a case of synovial sarcoma arising in the right infra-auricular region. A 29-yearold woman presented with a 2-months' history of a growing and slight painful tumor in the infra-auricular region. Pleomorphic adenoma arising from the lower pole of the parotid gland was suspected based on the findings of MRI and fine needle aspiration cytology of the tumor, and the tumor was resected. However, additional dissection was necessitated by the final diagnosis of synovial sarcoma by histopathological examination of the resected tumor. The SYT fusion gene from chromosomal translocation was detected by fluorescence in situ hybridization. Eight months later, a recurrent tumor was detected in the almost same region, and further dissection was performed with preservation of the mandibular branch of the facial nerve. The patient was administered postoperative radiotherapy at the dose of $60 \mathrm{~Gy}$, even though it was possible to resect the tumor with an adequate safety margin.
\end{abstract}

Keywords : synovial sarcoma, cervical region, SYT gene, recurrence

\section{References}

1) Masuda $Y$, Kohno N, Matsumura $Y$, et al. : A case of synovial sarcoma of the parapharyngeal space. Pract Otol (Kyoto) 93: 959-965, 2000.

2) Yamaura A, Katoh A, Ohbuchi T, et al. : A case of synovial sarcoma in the neck. Pract Otol (Kyoto) 105: 779-785, 2012.

3) Nomura F, Ito $T$ and Kishimoto S: Orohypopharyngeal synovial sarcoma in a 10-year-old child. Pract Otol (Kyoto) 104: 123-127, 2011.

4）中川俊一, 劉 澤周, 黒田 徹, 他 : 副咽頭間隙に発症し た滑膜肉腫の 1 例。耳鼻・頭頸外科 70: 557-561, 1998.

5) Tanabe M, Yamamoto E, Ohmura M, et al. : A case of synovial sarcoma of the neck. Pract Otol (Kyoto) 88: 759-763, 1995.

6) Ota R, Hayashi T, Nagato T, et al. : A case of synovial sarcoma of the larynx. Pract Otol (Kyoto) 100: 447-454, 2007.

7）千々和秀記, 森 一功, 山口勝矢, 他：頸部に発生した滑 膜肉腫の 1 例. 耳鼻と臨 45：109-112, 1999.

8) Miyake N, Takahashi H, Fujihara Y, et al. : Synovial sarcoma of the tongue. Pract Otol (Kyoto) Suppl 102: 105-108, 1999.
9）平山方俊，高橋廣臣，八尾和雄，他：側頭下窩に発生した 滑膜肉腫. 耳鼻・頭頸外科 72: 491-495, 2000.

10) Hirsch RJ, Yousem DM, Loevner LA, et al. : Synovial sarcomas of the head and neck: MR findings. AJR Am J Roentgenol 169: 1185-1188, 1997.

11）三好智之, 村松慶一, 伊原公一郎, 他 : 滑膜肉腫の治療成 績. 整外と災外 60：664-666, 2011.

12) Amble FR, Olsen KD, Nascimento AG, et al. : Head and neck synovial cell sarcoma. Otolaryngol Head Neck Surg 107: 631637, 1992.

13）上田孝文, 内田淳正, 吉川秀樹, 他：軟部肉腫における補 助化学療法. 整形外科 43: 1387-1393, 1992.

14) Harb WJ, Luna MA, Patel SR, et al. : Survival in patients with synovial sarcoma of the head and neck: association with tumor location, size, and extension. Head Neck 29: 731-740, 2007.

15) Carrillo R, Rodriguez-Peralto JL and Batsakis JG : Synovial sarcomas of the head and neck. Ann Otol Rhinol Laryngol 101: 367-370, 1992.

16）荒井孝和，川口智義：滑膜肉腫の臨床病理学的検討. 日整 会誌 49：253-271, 1975.
1) Department of Otolaryngology, Head and Neck Surgery, Osaka Medical College

2) Department of Diagnostic Pathology, Osaka Medical College
Corresponding Author Address : Yusuke Ayan oto095@poh.osaka-med.ac.jp 

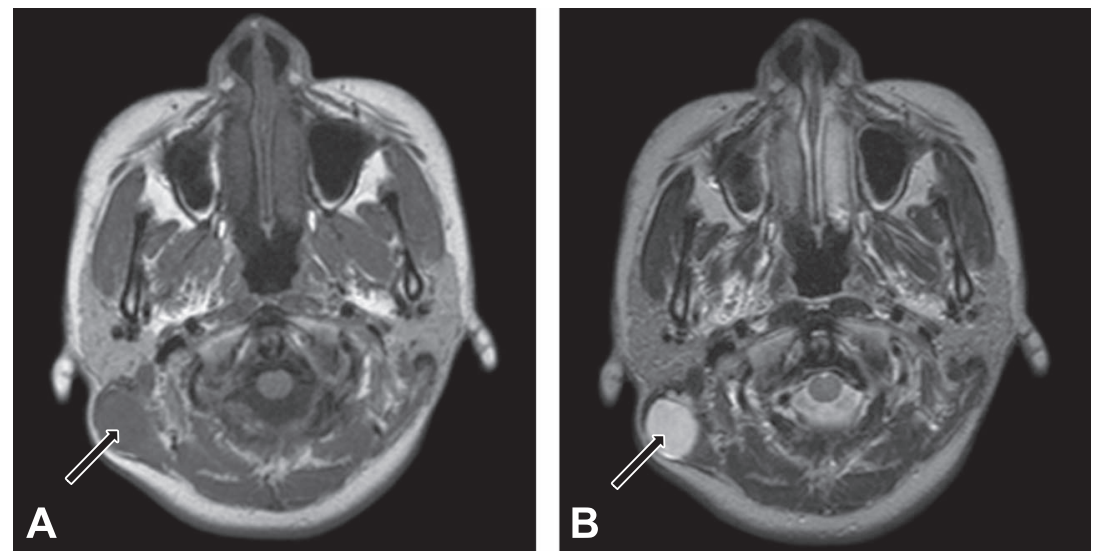

MRI findings before first operation (axial view)

The tumor is localized in contact with the right parotid gland. The tumor shows low intensity under T1 weighting (A) and high intensity under T2 weighting (B).
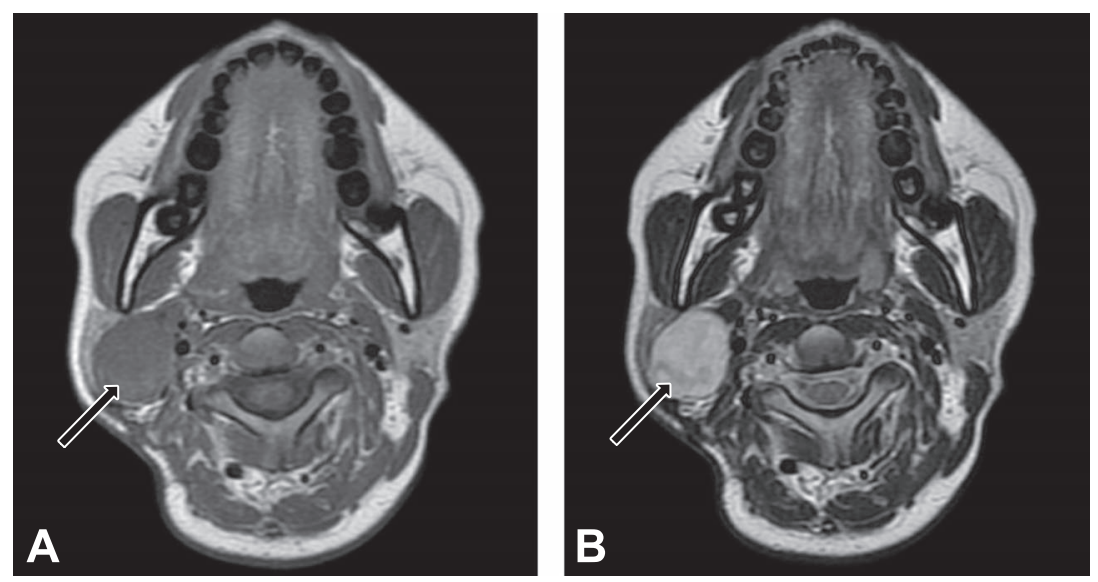

MRI findings before the third operation (axial view)

The tumor has recurred in the same region. In addition, MRI findings show the same intensity under T1 (A) and T2 weighting (B).

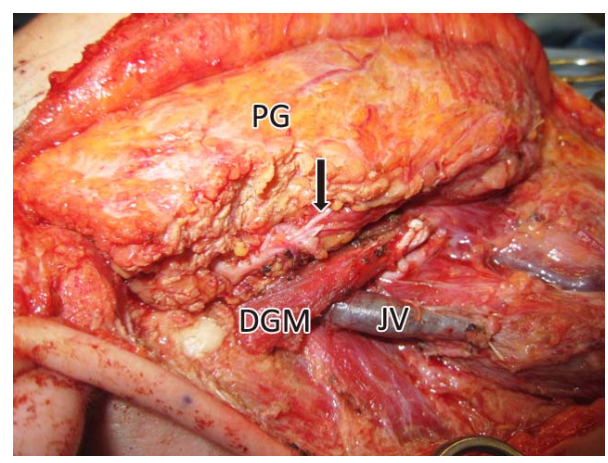

Intraoperative findings of the third operation

The tumor has been dissected together with the lower pole of the parotid gland. The mandibular branch of the facial nerve has been preserved (arrow). (PG: parotid gland, DGM: digastric muscle, JV: jugular vein) 